\title{
Elegie żydowskie upamiętniające wydarzenia połowy XVII wieku
}

Anna Michałowska 
nAPクS Seria VII 2001

\section{Anna Michałowska}

\section{Elegie żydowskie upamiętniające wydarzenia połowy XVII wieku}

$\mathrm{P}_{\mathrm{s}}^{\mathrm{s}}$ ołowa wieku XVII uważana jest za swego rodzaju cezurę w dziejach Rzeczypospolitej i mieszkających na jej terenach Żydów.

Wybuch w 1648 roku powstania kozackiego pod wodzą Chmielnickiego na południowo-wschodnich terenach Rzeczypospolitej był bardzo dotkliwy w skutkach dla tamtejszej ludności zydowskiej. Przeciwko Żydom, stanowiącym element znienawidzonego systemu ekonomicznego, pełniącym rolę arendarzy i zarządców, kozacy zwracali się w pierwszej kolejności. Żydzi uciekali z zagrożonych terenów i chronili się w dużych i obwarowanych miastach. Tych, którzy nie zdążyli uciec, spotykała na ogół śmierć, nieraz zadawana w wyrafinowanych męczarniach.

$\mathrm{Na}$ określenie męczeńskiej śmierci, poniesionej za wiarę, używany był termin kidusz ha-Szem (hebr. קדוש השם) czyli „uświęcenie imienia Bożego”, a przy nazwiskach męczenników dodawano określenie „święty” (hebr. קדוש). Rzeziom towarzyszyło niszczenie synagog i zwojów Tory, a czasem także przymusowe chrzczenie Żydów. Stosunkowo lepsze było dostanie się do niewoli tatarskiej, skąd istniała nadzieja zostania wykupionym przez współbraci ze Stambułu. Straty poniesione przez ludność żydowską na Ukrainie w czasie powstania Chmielnickiego, mimo gigantycznych liczb podawanych przez kronikarzy, oceniane są na 20-25\%, co w zależności od szacunków liczebności Żydów w tym okresie waha się od około 6 do 15 tys.

Kolejną falę pogromów Żydów w połowie XVII wieku przyniosły na terenach wschodnich przemarsze wojsk moskiewskich, a w centralnej i zachodniej Rzeczypospolitej najazd szwedzki oraz działania wojsk szwedzkich, brandenburskich i polskich ${ }^{1}$. Podczas najazdu szwedzkiego i wojny polsko-szwedzkiej (1655-1660) w całej Koronie zginęło $3200-3580$ rodzin żydow-

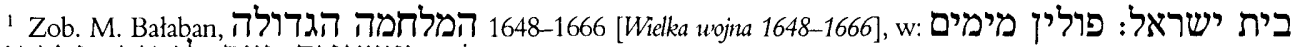
בŻydzi w Polsce. Od poczq̨tków do czasów zniszczenia], wyd. I. Halpcrin, t. 1, Jerozolima 1948, s. 81-90; J. Schamschon, Beiträge zur Geschichte der Judenverfolgungen in Polen während der Jahre 1648-1658, Bern 1912; L. Lewin, Die Judenverfolgungen im zweiten schwedisch-polnischen Kriege (1655-1659), „Zcitschrift der Historischen Gesellschaft für Provinz Posen”, t. 16, 1901, s. 79-101. 
skich $^{2}$, przeważnie wymordowanych przez wojska Czarnieckiego w odwecie za rzekomą współpracę Żydów ze Szwedami. Spustoszeń dopełniała zaraza, bieda, drożyzna i głód.

Doświadczenia połowy XVII wieku, zwłaszcza rzezie kozackie, spowodowały znaczny wzrost wrażliwości na zagrożenie wśród żydowskiej ludności Rzeczypospolitej ${ }^{3}$. Rozmiar zniszczeń, często co prawda wyolbrzymianych w przekazach, spowodował, że zaczęto nadawać wydarzeniom połowy XVII wieku specjalne znaczenie, interpretując je między innymi jako „bóle porodowe” poprzedzające przyjście mesjasza.

Wydarzenia $\mathrm{z}$ tego okresu zostały uwiecznione w dwóch typach tekstów.

Pierwszy typ stanowią kroniki. Najbardziej znana jest kronika Natana Hanowera z Zasławia, zatytułowana Jewen mectula (hebr. יון מצולה-Bagno głębokie”), wydana w 1653 roku w Wenecji ${ }^{4}$. Obraz nieszczęść, jakie spotkały Żydów na Ukrainie, Hanower uzupełnił idyllicznym opisem rozkwitu żydowskich instytucji samorządowych i życia duchowego przed rokiem 1648. Innymi kronikami z tego okresu są: Cok ha-itim (hebr. צוק העתים - „Ciężkie czasy”) Meira Samuela ze Szczebrzeszyna, Megilat eifa (hebr. Zwój ciemności”) Sabataja

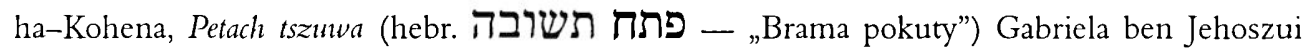
Szusberga, Tit ha-jawen (hebr. בטיט היךן - „Głębokie bagno”, „Wielkie zmartwienie”) Samuela Fajwla ben Natana z Wiednia oraz Car bat rabim (hebr. צער בת - צ' _ „Udręka licznych”) Abrahama ben Samuela Aszkenazi ${ }^{5}$. Kroniki te powstawały prawie natychmiast po wydarzeniach i stanowiły pierwsze spisane o nich relacje. Celem, który przyświecał kronikarzom, było przede wszystkim utrwalenie wydarzeń dla tych, którzy przeżyli. Wszystkie kroniki pisane były po hebrajsku, a dokładniej w zarameizowanej formie tego języka, kształtowanej pod wpływem Talmudu i innych pism rabinicznych.

Drugi typ tekstów stanowią modlitwy. Przeważają wśród nich elegie - teksty żałobne

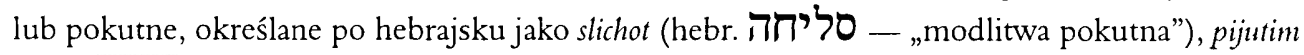

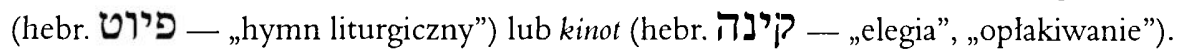

Teksty te pełniły funkcję użytkową, przeznaczone były do publicznego odmawiania w synagodze i włączane do liturgii. Odmawianie ich było silnie zakorzenione w tradycji żydowskiej: w każdą rocznicę śmierci (jid. יארָרצי יאריט) krewni zmarłego zobowiązani byli odmówić w jego intencji kadisz (hebr. קישד) - modlitwę za zmarłych. Standardowy tekst tej modlitwy, zaczynającej się od słów El male rachamim (hebr. אל מלא רחמים) - „Boże pełen miłosierdzia”), znajdował się w modlitewnikach; w odpowiednim miejscu tekstu wymieniano imię zmarłego.

W „szczególnych” przypadkach układano specjalne modlitwy. W ten sposób upamiętniano przede wszystkim osoby, które oddały życie za wiarę, na przykład ofiary posądzeń o profanację hostii czy mord rytualny, a także ofiary różnych pogromów i rzezi. Elegie takie powstawały

${ }^{2}$ Zob. Z. Guldon, Ludnos̈ ż zydowska w miastach matopolskich i czerwonoruskich w drugiej polowie XVII wieku, w: idem, Żydzi i Szkoci w Polsce XVI-XVIII wieku. Studia i materialy, Kiclcc 1990, s. 88.

${ }^{3}$ Zob. M. J. Rosman, Jeurish Perceptions of Insecurity and Powerlessness in $16^{\text {th }}-18^{\text {th }}$ Century Poland, „Polin”, t. 1, 1986, s. $19-27$.

${ }^{4}$ Zob. N. Hanower, Jewen Mecula, w: Kroniki, opisy i elegie hebrajskie z czasów Chmielnickiego, wyd. M. Bałaban, „Ruś”, t. 1, 1911, z. 1, s. 46-63; z. 2, s. 152-176; z. 3, s. 285-300; z. 4, s. 397-412.

5 Zob. B. D. Wcinryb, The Hebrew Chronicles on Bohdan Khmel'nyts'kyi and the Cossack-Polish War, „Harvard Ukrainian Studies", t. 1, 1977, s. 164. 
przed połową wieku XVII wieku, a rozmiar nieszczęść spotykających ludność żydowską w tym okresie spowodował ożywienie tego typu twórczości ${ }^{6}$.

W tekstach elegii upamiętniających wydarzenia połowy XVII wieku widać wiele podobieństw. Jest to zapewne spowodowane ich kopiowaniem czy przerabianiem na potrzeby miejscowych wydarzeń. Później elegie były często powielane w różnych rękopiśmiennych czy drukowanych zbiorach, zapisywano je także na ścianach synagog. Większość elegii pisano, wykorzystując różnego rodzaju struktury zwrotkowe, niekiedy używając rymów.

Wiele elegii rozpoczyna początek modlitwy za zmarłych:

„Boże pełen milosierdzia, mieszkający w niebiosach, daj prawdziwy odpoczynek w górze, pod skrzydłami Szechiny [Bożej obecności - A. M.], na wysokościach świętych i czystych, lśniących jak blask firmamentu, duszom świętych i niewinnych..."

Ofiary prześladowań wymienia się albo imiennie (podając imię, imię ojca, tytuły, pełnioną funkcję), albo ogólnie, jako starców, młodzieńców, uczonych i tak dalej. Ważniejsza była ogólna pamięć o wydarzeniu niż konkretne informacje historyczne. Oprócz osób wymieniano zniszczenie zwojów Tory i świętych ksiąg.

O śmierci prześladowanych mówi się w elegiach jako o ofierze, składanej Bogu. Wymieniano różne rodzaje śmierci, jakimi zostali unicestwieni, podkreślając, że wybrali śmierć dla uświęcenia Imienia Bożego, a nie bałwochwalstwo (czyli konwersję). W usta umierających autorzy elegii często wkładali wyznanie wiary:

„Słuchaj, Izraelu! Pan jest naszym Bogiem. Pan jest jeden!"’

W niektórych elegiach pojawia się motyw Akedy — ofiary złożonej przez Abrahama ze swojego ukochanego syna Izaaka. Motyw ten pojawiał się już wcześniej, w kronikach opisujących prześladowania Żydów w czasie krucjat ${ }^{8}$.

W wielu elegiach znajdujemy przekonanie, że opisywane wydarzenia mają głębsze znaczenie, że sprawiedliwy Bóg pomści wylaną krew, zbierze rychło rozproszony lud Izraela, ześle mesjasza i odbuduje Świątynię.

Elegie pisane są w języku hebrajskim, podobnie jak inne teksty pełniące funkcje liturgiczne. Już sam ten fakt, a także używanie różnych odniesień i cytatów biblijnych i talmudycznych pokazuje, że autorami tekstów byli uczeni: rabini, kaznodzieje, nauczyciele, kantorzy czy szamesi ${ }^{9}$. Niekiedy teksty stanowią akrostych, gdzie w pierwszych literach wersów zawarte jest imię autora.

Modlitwy miały nie tylko wymiar jednostkowy, lecz także znaczyły wiele dla całej społeczności. Były wyrazem pamięci zbiorowej, a przypominanie wydarzeń było czynnikiem jednoczącym wspólnotę. Wspominanie poległych stawało się obowiązkiem tych, którzy przeżyli, nie tylko krewnych, ale i całej gminy. Wynikało to nie tylko z tego, że często w rzeziach ginęły całe rodziny, ale było także wynikiem przekonania o konieczności utrwalenia imion męczenników, tych szczególnie miłych Bogu, którzy oddali życie dla uświęcenia Jego Imienia ${ }^{10}$. Ich śmierć była czynnikiem

${ }^{6}$ O nawiązywaniu w połowie XVII wieku do prześladowania Żydów w czasie krucjat i do powstających wówczas

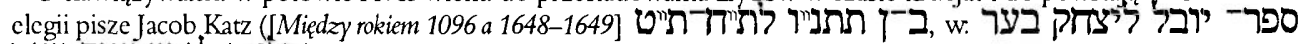
במלאת לו שבעים שונה, Jerozolima 1961, s. 318-337).

7 Pwt 6, 4; tu i dalej sigla biblijne za Biblią Tysiąclecia.

8 Y. H. Yerushalmi, Zakhor. Jewish History and Jewish Memory, Seattle-London 1982, s. 38.

9 Szames - pomocnik, funkcjonariusz angażowany przez kahał, bractwa itd.

${ }^{10}$ Wśród Żydów aszkenazyjskich rozpowszechniony był zwyczaj zapisywania wybitnych osób w księgach pamiątkowych (tzw. Memorbuch). Wpisywano do nich nazwiska wybitnych rabinów i przywódców władz gminnych, osób 
zapewniającym łaskę i pomyślność dla ocalałych mieszkańców gminy, przybliżającym nadejście mesjasza. W wielu gminach modlitwy upamiętniające ofiary wydarzeń połowy XVII wieku odmawiane były aż do czasów drugiej wojny światowej ${ }^{11}$.

Każda gmina czciła swoje własne wydarzenia, ale były także rocznice o szerszym zasięgu. Szczególną datę stanowił dzień 20 siwan. W tym dniu miała miejsce rzeź w Niemirowie, od której zaczęły się masakry w czasie powstania Chmielnickiego. Współcześni zwracali uwagę, że dzień 20 siwan był już w przeszłości datą nieszczęśliwych wydarzeń dla Żydów. W tym dniu, w 1171 roku, w Blois spalono na stosie 32 Zydów, oskarżonych o dokonanie mordu rytualnego. Oba te wydarzenia wiązano ze sobą i w wydarzeniach połowy XVII wieku widziano kontynuację wcześniejszych prześladowań. Na zbieżność tych dwóch wydarzeń zwracał uwagę w swojej kronice Sabataj Kohen, a Jom Tow Lipman Heller wykorzystał elegie powstałe po wydarzeniach w Blois i nakazał ich odmawianie dla upamiętnienia pogromów w 1648 roku $^{12}$. Bardzo szybko dzień 20 siwan stał się terminem postu we wszystkich gminach Rzeczypospolitej, co zarządził Sejm Czterech Ziem w $1650 \mathrm{roku}^{13}$.

Oprócz elegii upamiętniających prześladowania i ich ofiary powstawały także modlitwy dziękczynne. Zgodnie z nakazem talmudycznym, w przypadku uratowania z opresji należało odmówić specjalne błogosławieństwo dziękczynne ${ }^{14}$. Zwyczaj ten kultywowały rodziny lub całe gminy, odmawiając specjalne modlitwy w rocznicę ocalenia. Ze względu na podobieństwo ze świętem Purim nazywano te dni Małym Purim (hebr. פורים קטן), Małym Świętem (hebr. מועד קטן) lub Purim danej gminy. Często dzień ten był poprzedzony postem, wzorowanym na Poście Estery. Przyczyną radości mogło być ocalenie w czasie zamieszek wojennych, pogromów, klęsk żywiołowych, przy oskarżeniu o przestępstwa rytualne albo otrzymanie przez gminę przywilejów ${ }^{15}$. Przykładem takiego lokalnego Purim może być Purim gminy Międzybórz, obchodzone 11 dnia miesiąca tewet, na pamiątkę uratowania gminy przed zniszczeniem w czasie rzezi kozackich w połowie XVII wieku.

Inny typ literatury, niejako uzupełniający modlitwy, stanowiły teksty pisane w języku jidysz, które Chava Turniansky nazywa piésniami „historycznymi” ${ }^{16}$. Opisywały one aktualne wydarzenia: klęski żywiołowe, prześladowania, cierpienia czasu oblężeń i wojny, tułaczkę, procesy i egzekucje, czasem zgony ważnych osobistości, spełniając w pewnej mierze funkcje dzisiejszej prasy.

zasłużonych na polu dobroczynności, a także zabitych w wyniku oskarżcń czy prześladowań. Listç tych osób odczytywano głośno w synagodze, podczas nabożeństw upamiçmiających zmarłych (zob. Y. H. Yerushalmi, op. cit., s. 46).

${ }^{11}$ Wydawca elegii sandomicrskich, Dawid Kandel, pisze, że ich coroczne odmawianic odbywa siç w bożnicy sandomierskicj „aż po dziś dzień” (zob. D. Kandel, Rzeź żydów sandomierskich w r. 1655, „Kwartalnik poświçcony badaniu przeszłości Żydów w Polsce”, t. 1, 1912/1913, z. 2, s. 111-117).

12 Zob. Y. H. Yerushalmi, op. cit., s. 50.

13 Zob. פנקס ועד ארבע ארצות [Pinkas Sejmu Czterech Ziem], wyd. I. Halpcrin, t. 1: 1580-1792, Jcrozolima 1989, s. 78, nr 207 (Lublin, 410/1650).

${ }_{14}$ Berachot 54a; błogosławieństwo to należało odmówić, wracając do miejsca, gdzie nastąpilo cudowne ocalenic.

15 Lista specjalnych Purim, obchodzonych przez gminy i rodziny żydowskic w Europic, zamicszczona jest w Encyclopaedia Judaica, t. 13, Jerusalem 1978, przy haślc Special Purims (kol. 1395-1400).

16 Zob. Ch. Turniansky, Pieśni „historyczne” w jezyku jidysz jako źródto do dziejów Żydów w Polsce przedrozbiorowej, w: Żydzi $w$ dawnej Rzeczypospolitej. Materialy z konferencji „Autonomia Żydów w Rzeczypospolitej szlacheckiej”, Wrocław 1991, s. 297-305. Jak podaje autorka, spośród 44 znanych obecnic XVII i XVIII-wiccznych picśni 9 opisuje wydarzenia, które miały miejsce w Rzeczypospolitej, z czego 2 dotyczą wydarzeń z połowy XVII wieku: jedna opisuje czasy Chmiclnickicgo, a druga wydarzenia na Litwic, Białorusi, w Lublinie i Lwowie z czasów wojny polsko-moskiewskiej w 1655 roku (s. 299-300). 
Język jidysz, używany na co dzień przez słuchaczy i dla wszystkich zrozumiały, dawał znacznie lepsze możliwości realistycznego i dokładnego opisu niż w hebrajskiej elegii poświęconej temu samemu wydarzeniu ${ }^{17}$.

\section{Aneks $^{18}$}

1. Elegia upamiętniająca nieszczęścia lat 1648-1649, którą napisał Szabtaj ben Meir ha-Kohen

אל רחמים שוכן מרומים, ברחמיו רבים העצומים מרומים יזכור לגמול עולמים. גאונים ורבנים גדולים העומים ורמים, תופשי המולי התורה תלמים ומידי חכמים,

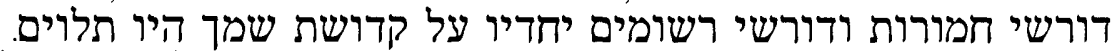

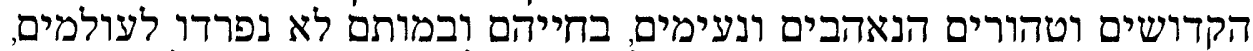

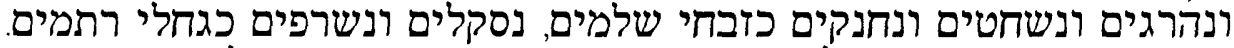
זקנים ונערים, שבים ועלמים וחים וחים היו נהרגים שלמים בבזיון בושים ונשרפים ונכלמים.

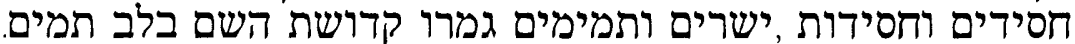

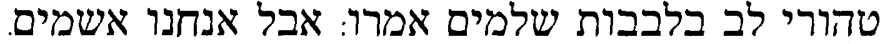

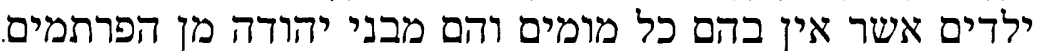

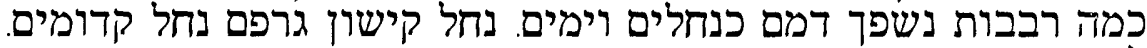
לאין מספר נהרגות באתים באתים וקרדומים ומים משל בגוים מנוד ראש בלאים באתומים ומרומים. מי יוכל לשער הנהרגים כל הימים, היו טובים חללי חרב כמור כשה פעמים פלמים. נשאו ראש שונאים חלינו רבים עלים פעי קמים עמים עלינו נלחמים - ערואינו

ספרי תורות אורים ותומים עים רמסו ושרפו עם נפשות קדושים ויהיו שניהם ערומים. ערו ערו יסודות ומשכנות ורומים מקדשינו ובתי כנסיותינו

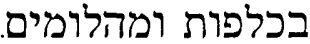

פרשו עלינו מצודות וחרמים וצים, אהלי אדום ישמעאלים ויתותר העמים מיפים

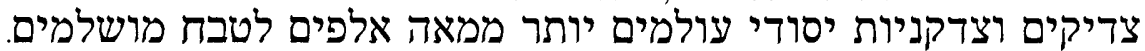

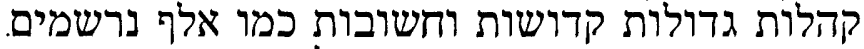

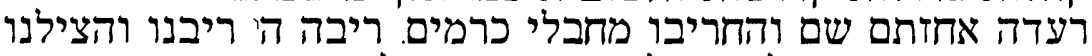

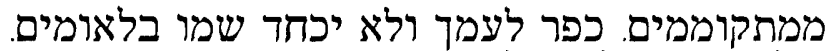

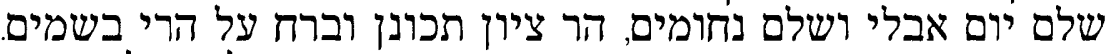

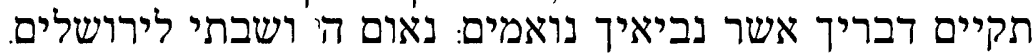

(S. Bernfeld, ספר הדמעות.מאורעות הגזרות והרדיפות והשמדות, t. 3, Berlin 1926, s. 161-162)

\footnotetext{
17 Zob. ibidem, s. 303.

18 Wszystkic tłumaczcnia: Anna Michałowska.
} 
Bóg pełen miłosierdzia, mieszkający w niebiosach, w swoim wielkim i niezmierzonym miłosierdziu oby pamiętał, aby odplacać wiecznie

mędrcom i rabinom wielkim i wybitnym, uczonym, genialnych uczniów, interpretatorom rzeczy ważnych i interpretatorom Tory [którzy] razem byli zależni od świętości Twojego Imienia.

Święci i czyści, ukochani i przyjemni, za swojego życia oraz w swojej śmierci nie zostali oddzieleni ${ }^{19}$ na zawsze,

Zostali zamordowani, zarżnięci i zaduszeni jak ofiary pojednania, ukamienowani i spaleni jak żar janowca 20.

Starcy i chłopcy, ludzie wiekowi i ludzie młodzi zostali zamordowani ze wzgarda, zawstydzeni i upokorzeni.

Pobożni i pobożne, prawi i niewinni dokonali uświęcenia Imienia [Bożego] w czystym sercu.

[Ludzie] czystego serca mówili w doskonałych sercach: To my jesteśmy winni!

Dzieci bez żadnej skazy, które były potomkami Jehudy, ludzi szlachetnych -

tak obficie została wylana ich krew jak rzeki i morza.

Strumień Kiszon zmiótł ich, strumień starożytny ${ }^{21}$.

Niezliczeni zostali zamordowani łopatami i siekierami.

Przykład wśród ludów, znajdujący uznanie w oczach [innych] narodów.

Kto będzie w stanie policzyć zamordowanych we wszystkie te dni, [ludzie] dobrzy zabijani mieczem wiele razy.

$\mathrm{Ci}$, którzy nas nienawidzą, podnieśli głowę, liczni powstali przeciwko nam, prostacy i Izmaelici ${ }^{22}$, i pozostałe narody walczą przeciwko nam.

Księgi Tory Urim i Tumim ${ }^{23}$ stratowali i spalili

wraz ze świętymi duszami, a jedni i drudzy byli pełni mądrości.

Zniszczyli, zniszczyli fundamenty i osady, które wznieśliśmy, nasze świątynie i nasze synagogi kilofami i ciosami.

Rozciągnęli na nas pułapki i sieci, namioty Edomu, Iszmaelitów $\mathrm{i}$ innych narodów.

Sprawiedliwi i sprawiedliwe - fundamenty świata, więcej niż sto tysięcy doskonałych na zarżnięcie.

Gminy wielkie, święte i ważne — na tysiąc obliczane.

${ }^{19} 2 \mathrm{Sm} 1,23$.

${ }^{20}$ Ps $120,4$.

2) Sdz 5, 21.

${ }^{22}$ We współczesnej literaturze słowa tego używano także na określenie Tatarów.

${ }^{23}$ אורים ותומים (Urim i Tumim) - element napierśnika najwyższego kapłana. 
Przerażenie ogarnęło ich tam i zniszczyli niszczycieli winnic ${ }^{24}$.

Bóg powiększył naszą wielkość i wybawił nas od buntowników.

Przebaczy swemu narodowi, niech nie zaginie jego imię wśród ludów.

Odpłać dzień żałoby i daj pocieszenie, przygotuj górę Syjon

i zbiegnij na góry w niebiosach.

Wprowadzisz w życie Twoje słowa, które mówią Twoi prorocy -

„Tak mówi Pan: I wrócę do Jerozolimy”25.

\section{Elegia upamiętniająca nieszczęścia 1648 roku}

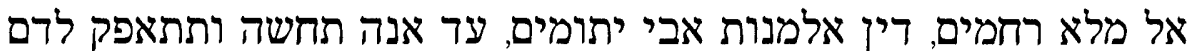

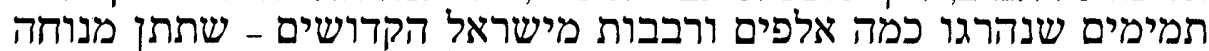

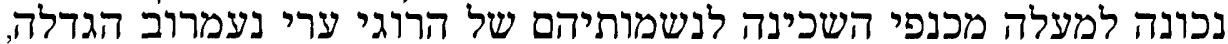

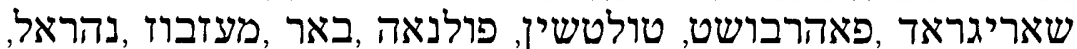

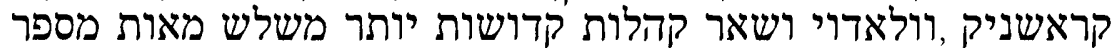

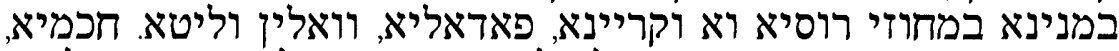

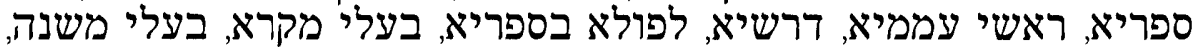

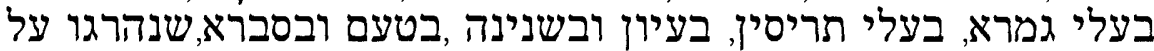

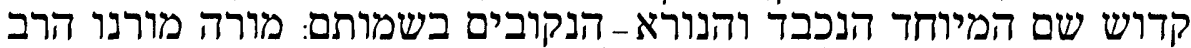

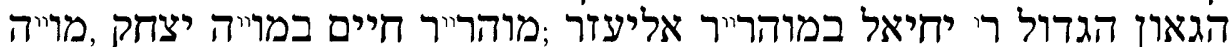

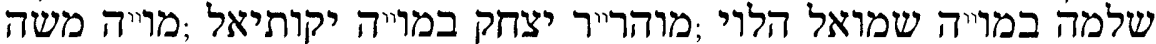

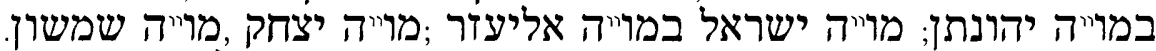

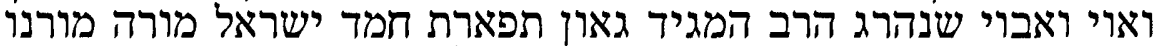

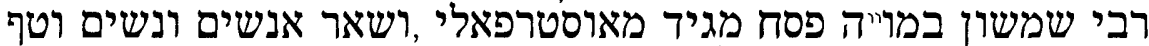

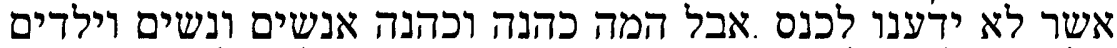

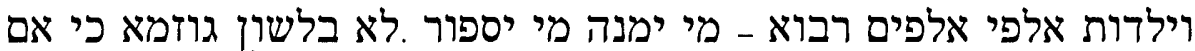

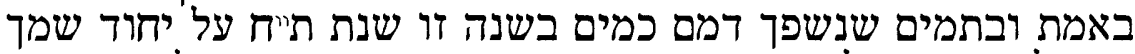
הגדול והנורא. ולתמים נסעו אחר בוגדיפדים כמים וקראו שמע ישראל ביחודא

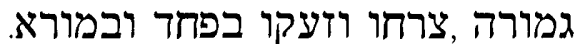

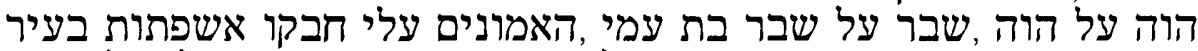

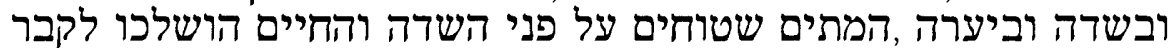

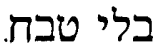

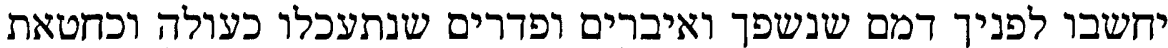

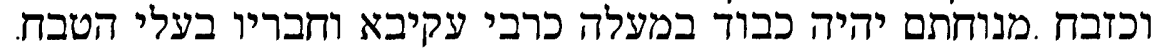

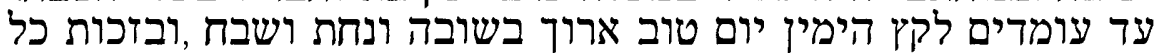
הצדיקים וצדקניות לקות הנפוצות כבמזרה.

(S. Bernfeld, op. cit., s. 160-161)

Boże pełen miłosierdzia, sędzio wdów, ojcze sierot, jak długo będziesz milczał i wstrzymywał się wobec krwi niewinnych, którzy zostali zamordowani — kilku tysięcy i licznych świętych Izraela

\footnotetext{
${ }^{24} \mathrm{Jr} 48,32$.

${ }^{25} \mathrm{Za} 8,3$.
} 
- że dasz prawdziwy odpoczynek w górze, pod skrzydłami Szechiny ich duszom, [duszom] zabitych miast wielkiego Niemirowa, Szarogrodu, Pohrebyszcza, Tulczyna, Połonnego, Baru, Międzyborza, Narola, Kraśnika, Włodawy i pozostałych świętych gmin, których jest ponad trzysta, w prowincjach Rusi i Ukrainy, Podola, Wołynia i Litwy. Mędrcy, pisarze, przywódcy ludu, kaznodzieje, poszukujący rozstrzygnięć w księgach, uczeni w Piśmie, znawcy Miszny, znawcy Gemary, szukający rozwiązań w studiach i w szyderstwie, w logice i racjonalnym myśleniu — ci, którzy zostali zamordowani dla uświęcenia szacownego i przejmującego lękiem Imienia Bożego wymienieni imiennie: morem ${ }^{26}$ rabin, wielki gaon reb Jechiel syn moremu reb Eliezera; morenu reb Chaim syn morenu pana Icchaka; morenu pan Szlomo syn morenu pana Szmuela Halewi; morenu reb Icchak syn morenu pana Jekutiela; morenu pan Mosze syn morenu pana Jehunatana; morenu pan Israel syn moremu pana Eliezera; morenu pan Icchak; morenu pan Samson. I — biada! — zamordowany został rabin, magid, gaon duma wspaniałości Izraela morenu rabin Szimszon syn morentu pana Pesacha magid z Ostropola; i pozostali mężczyźni, kobiety i dzieci, których nie potrafımy zgromadzić. Ale jest ich tak wielu mężczyzn, kobiet, chłopców i dziewczynek - tysiące tysięcy, kto [ich] wymieni i kto policzy. Nie tylko w sposób przesadzony, ale w prawdzie i szczerości, że została przelana ich krew jak woda w tym roku, roku 408 dla jedynego Twojego Imienia, wielkiego i przejmującego lękiem. I nie poszli drogą niewiernych i wołali „Słuchaj, Izraelu!”27, wyznając jedyność Boga; wołali i krzyczeli w strachu i w przerażeniu.

Ruina na ruinie, zniszczenie na zniszczeniu - córko mojego narodu ${ }^{28}$, wierzący we mnie przytulili się do śmietnisk ${ }^{29}$ w mieście, na polu i w lesie, zmarli leżą po polach, a żywi zostali wrzuceni do grobu niezabici.

Będą rozważać przed Tobą ich przelaną krew i części [ciała], i tłuszcz, które zostały strawione jako ofiara całopalna, ofiara przebłagalna i ofiara rzeźna. Ich odpoczynkiem będzie chwała na wysokościach, jak [chwała] rabiego Akiwy i jego zabitych towarzyszy, [wraz z] czekającymi na kres dni, długi dzień świąteczny w pokoju, ukontentowaniu i chwale, i ze względu na zasługi wszystkich sprawiedliwych mężczyzn i kobiet, którzy zasłynęli na Wschodzie.

\section{Elegia upamiętniająca nieszczęścia lat 1648-1649}

$$
\begin{aligned}
& \text { אל מלא רחמים הוא יפקוד ברחמים העצומים הנפשות הקדושות }
\end{aligned}
$$

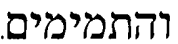

$$
\begin{aligned}
& \text { קהלות קדושים וחים שמסרו נפשם על קדושת השם כעולה וכחטאת וכאשם }
\end{aligned}
$$

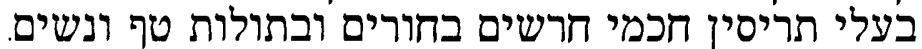

$$
\begin{aligned}
& \text { בקהלה המפוארה קייק לובלין, נהרגו שמים שמה תלי תלים תלין. שבת משוש חדוה } \\
& \text { וגילין, נפשם בטוב תלין. }
\end{aligned}
$$

\footnotetext{
26 morenu (hebr. מרובנ, ,nasz nauczycicl”) - tytuł honorowy przyznawany uczonym posiadającym kwalifikację rabiniczną (mogącym pełnić rytuały rabiniczne i podejmować decyzje halachiczne, kiedy nie ma rabina). $Z$ czasem nastąpiła deprecjacja tytułu morenu, kiedy zaczął on być kupowany przez najbogatszych micszkańców dla swoich synów czy ziçciów i utracił swój bezpośredni związck z wykształceniem.

27 Pwt 6, 4.

28 Lm 3, 47-48.

${ }^{29} \operatorname{Lm~4,~} 5$.
} 
הנמלטים מחרבות השיגום בקי"ק קורבא האכזרים, והרגו זקנים ומים נשים ואנשים, בתולות ובחורים השים, שפכום דמם כמים כמים המורים המוגרים.

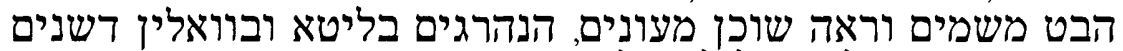

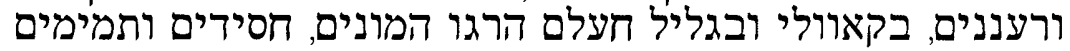

אבות ובנים. - בעלים

בכל הסביבות עשו בהם שפטים, אבות ואמהות ובנים נשחטים - אתה יובים

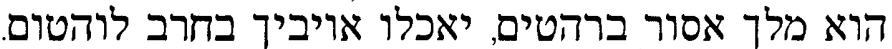

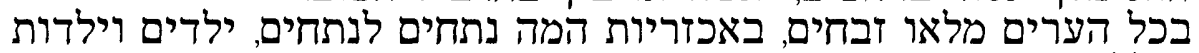

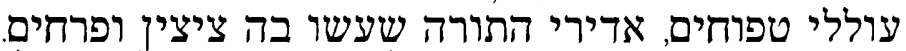

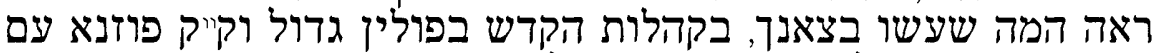

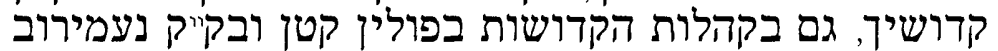

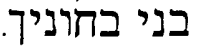

שכך נא חרון אפך, על יתר הפלטה יכליכמרו רחמיך, בזכות הקדושים

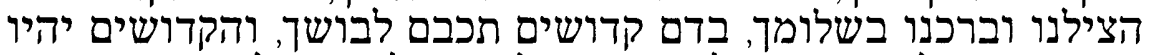

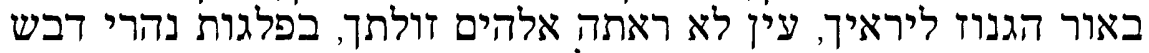
וחמאה יזכרו בחוניך, הנהרגים עיר על קדוש שמך. רוח הי תנחם ביגות נחרי

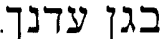
לפנים ממלאכי השרת תהיה מחים מיצתם, השלום יהיה במושבותם, הנאהבים

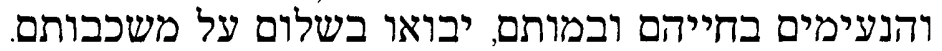

(S. Bernfeld, op. cit., s. 162-163)

Bóg pełen miłosierdzia — on w niezmierzonym miłosierdziu

pomści dusze świętych kobiet i niewinnych mężczyzn,

święte gminy, które przekazały swoje dusze na uświęcenie

Imienia Bożego jako ofiarę całopalną, jako ofiarę za grzechy

i jako ofiarę przebłagalną; [dusze] strzegących Prawa, mędrców,

rzemieślników, młodzieńców i dziewcząt, dzieci i kobiet.

We wspaniałej gminie, świętej gminie Lublin, tam pozostały ruiny ruin.

Szabat jest pogodny, radosny i szczęśliwy,

ich dusze spoczną w dobru.

Uciekinierów ze zniszczenia dopadli okrutnicy w świętej gminie Kurów i wymordowali starców, kobiety i mężczyzn, dziewczęta i młodzieńców, przelali ich krew niszczyciele jak wodę ${ }^{30}$.

[Pan] spojrzał z niebios i ujrzał cierpiących, zamordowanych na urodzajnej i kwitnącej Litwie i Wołyniu; w Kowlu i w okręgu Chełm zamordowali licznych, pobożnych i niewinnych ojców i dzieci.

We wszystkich przykahałkach ukarali ich surowo; ojcowie, matki i dzieci zostali zarżnięci. Ty, który jesteś królem zaplątanym w lokach ${ }^{31}-$

${ }^{30}$ Ps 79,3 .

${ }^{31}$ Pnp 7,6. 
pochłoną Twoich wrogów palącym mieczem.

We wszystkich miastach dokonali ofiary, w okrucieństwie

poćwiartowani na części, chłopcy i dziewczynki,

pieszczone niemowlęta, potężni Torą,

którzy uczynili z niej diadem i ozdobę.

Zobacz tych, którzy tworzą Twoją trzodę, w świętych gminach

w Wielkopolsce i w świętej gminie Poznań — naród Twoich świętych,

również w gminach w Małopolsce i w świętej gminie Niemirów poddanych Twej próbie.

Ucisz swój gniew, niech Twoje miłosierdzie rozszerzy się

na resztę uciekinierów, ze względu na zasługę świętych ocal nas, a nasze pobłogosław nas Twoim pokojem, w krwi świętych obmyj swą szatę, a święci będą w ukrytym świetle z bojaźni przed Tobą, oko nie widziało Boga oprócz Ciebie, w strumieniach rzek miodu i masła będą pamiętać Twoją próbę, zamordowani dla uświęcenia Twojego Imienia. Duch Boga będzie pocieszony w Twoim ogrodzie Edenu.

Aniołom usługującym będą bliscy, pokój nastanie w ich siedzibach, ukochani i przyjemni za swojego życia i w swojej śmierci dotrą do swego miejsca spoczynku w pokoju!

\section{Elegia upamiętniająca zamordowanych w Niemirowie,} ułożona przez Sabataja Halewi

אל מלא רחמים שוכן במרומים, המצא מנוחה נכונה למעלה מכנפי מירי

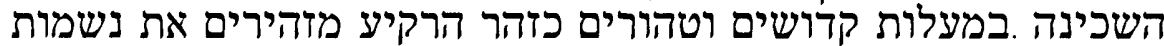

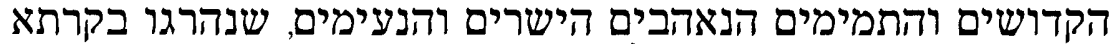

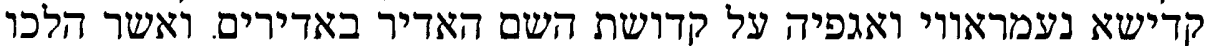

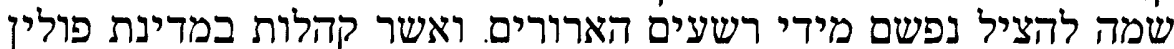

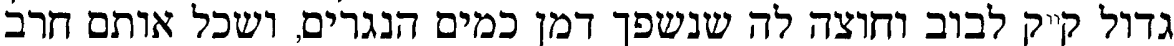

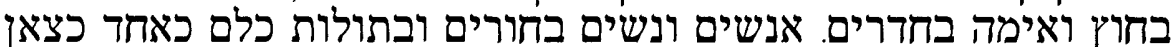

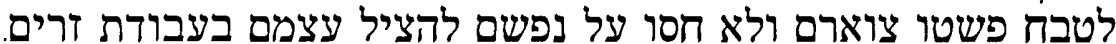

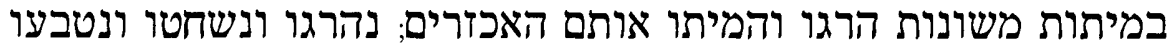

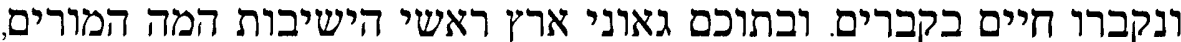

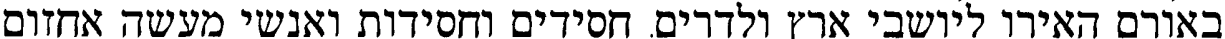

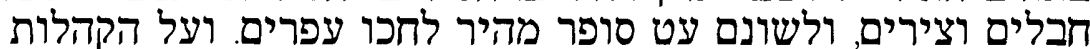

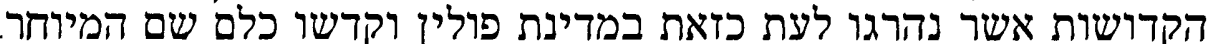

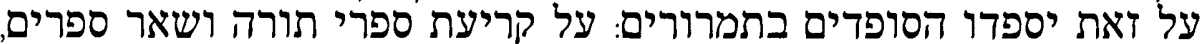

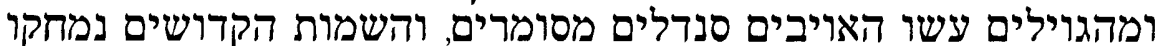

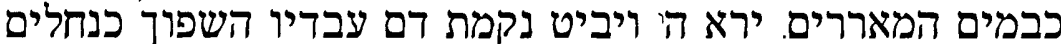
וכיאורים. ויערב לנו זביחתם כדם אילים ופים ופרים. 
Boże pełen miłosierdzia, mieszkający w niebiosach, daj prawdziwy odpoczynek w górze, pod skrzydłami Szechiny, na wysokościach świętych i czystych, lśniących jak blask firmamentu, duszom świętych i niewinnych, ukochanych, uczciwych i miłych, którzy zostali zabici w świętym mieście Niemirów i jego okolicach dla uświęcenia Imienia Bożego - najpotężniejszego spośród potężnych. I tych, którzy poszli tam, aby uratować swoje dusze z rąk przeklętych złoczyńców. I tych gmin, które są w Wielkopolsce, świętej gminy Lwów i [gminy] poza [miastem], ponieważ została przelana ich krew jak wylana woda $^{32}$ i ponieważ dosiąg ich miecz na ulicach, a przerażenie w izbach ${ }^{33}$. Mężczyźni i kobiety, młodzieńcy i dziewczęta — wszyscyjakjeden, jak stado na rzeź pochylili swoje karki i nie próbowali uratować się za pomocą bałwochwalstwa. Różnymi rodzajami śmierci zabili i uśmiercili ich okrutni, zostali zabici i zarżnięci, utopieni i pogrzebani żywcem w grobach. A wśród nich są mędrcy szeroko uznani, rektorzy jesziw, nauczyciele — swym światłem opromieniali żyjących na ziemi i mieszkańców. Pobożni i pobożne oraz ludzie czynu schwytani, w bólach i więzach, a językiem swym — narzędziem wprawnego pisarza 34 —żarli kurz. I wszystkie święte gminy, które zostały wymordowane w tym czasie w państwie polskim, w szczególny sposób uświęciły Imię Boga. Oto, co będą gorzko opłakiwać lamentujący: podarcie zwojów Tory i pozostałych ksiąg, a z pergaminu wrogowie zrobili okute sandały, a imiona świętych zostały wymazane, jak w wodach przekleństwa ${ }^{35}$. Oby Bóg wejrzał i pomścił krew swoich sług, która płynęła jak rzeki i strumienie i oby była nam przyjemna ich ofiara jak krew kozłów i byków.

\section{Modlitwa upamiętniająca zamordowanych w 1655 roku w Sandomierzu}

אל מלא רחמים שיכן במרומים המציא מנוחה נכוחונה בצל כנפי משי השכינה

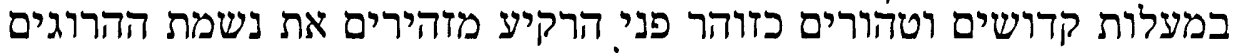

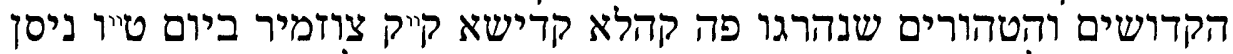

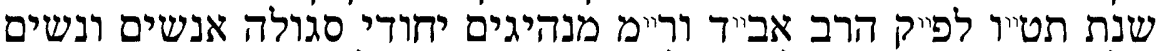

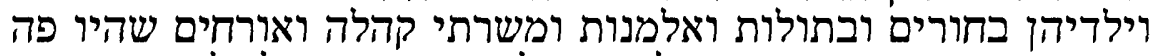

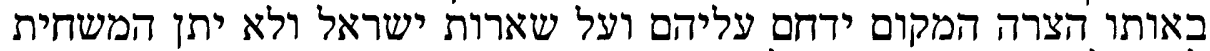

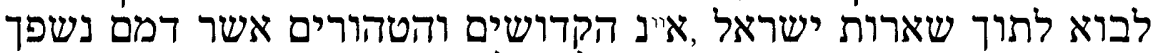

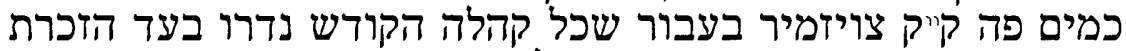

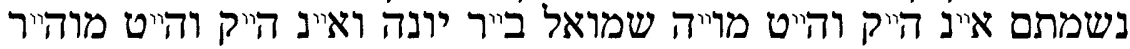

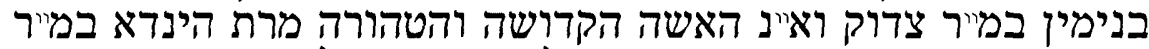

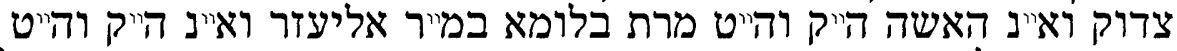

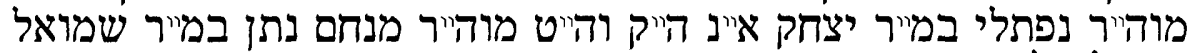

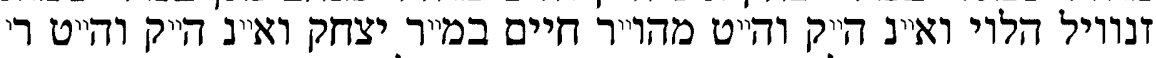

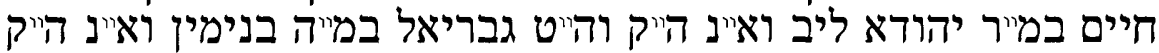

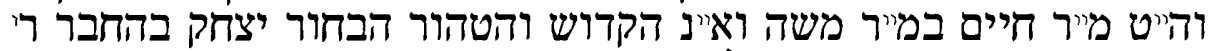

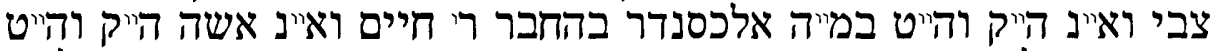
מרת פעסיל בת חבר רי פנחס ואייני בניהם ביהם הקדושים והטהורים הבתולה ואים

\footnotetext{
32 Ps 79,3 .

${ }^{33} \mathrm{Lm} \mathrm{1,20.}$

34 Ps 45, 2.

35 Lb 5, 22.
} 
שרה והבחור בנימין בינישו והילד חיים בניהם של הייק חבר רי אלכסנדר

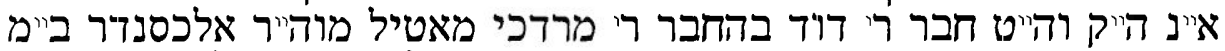

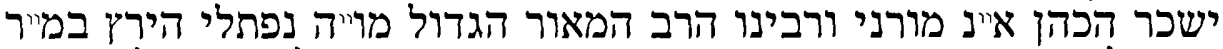

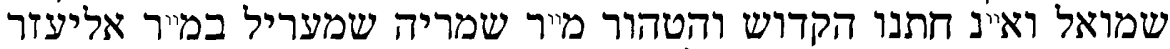

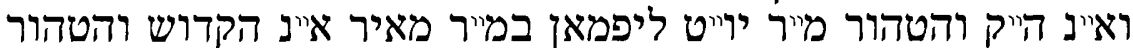

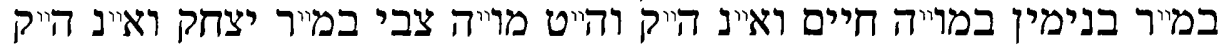

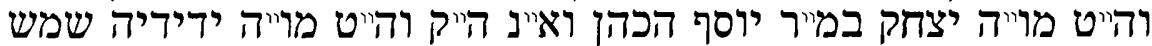

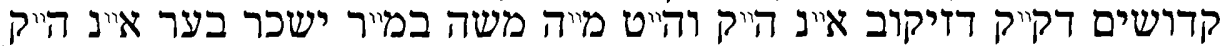

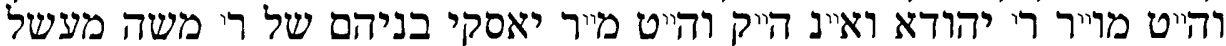

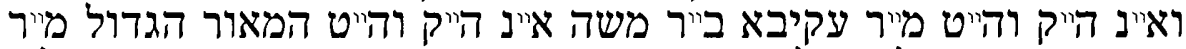

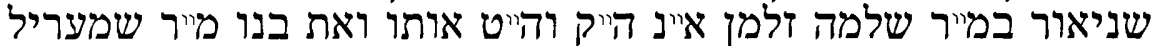

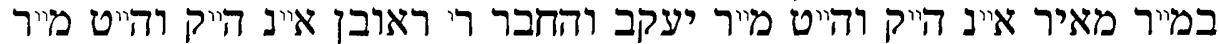

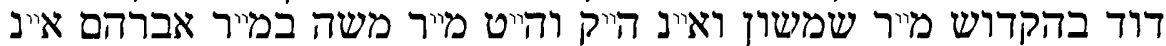

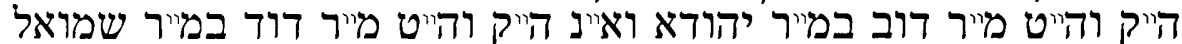

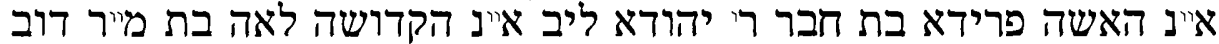

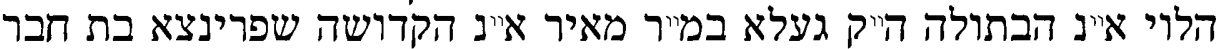

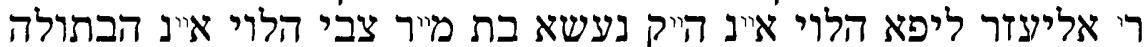

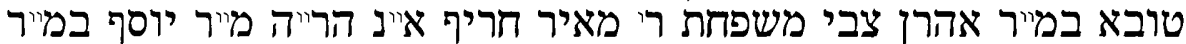

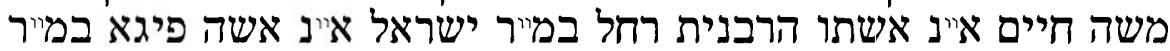

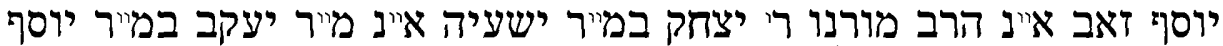

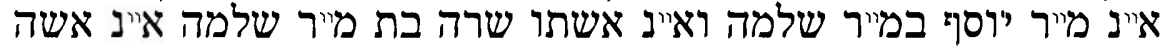

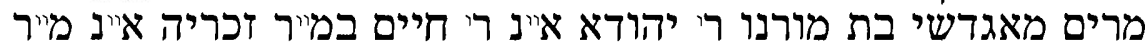

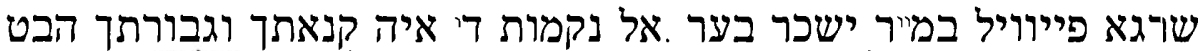

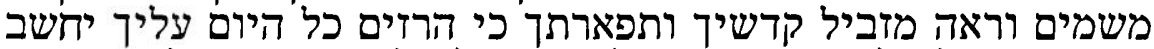

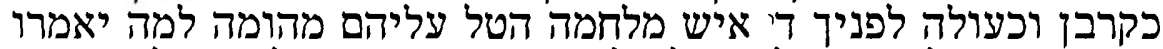

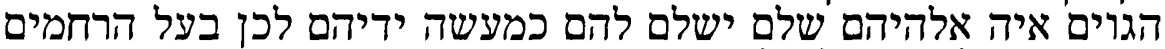

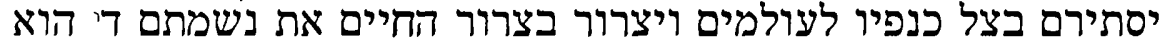

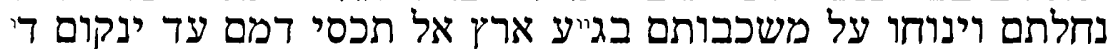

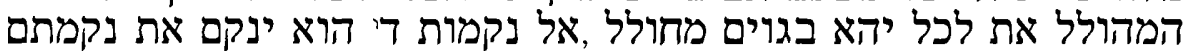

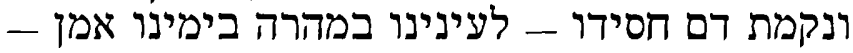

(D. Kandel, Rzéż் żdów sandomierskich $w$ r. 1655 , op. cit., z. 2, s. 112)

Boże pełen miłosierdzia, mieszkający w niebiosach, daj prawdziwy odpoczynek w cieniu skrzydeł Szechiny na wysokościach świętych i czystych, lśniących jak blask firmamentu, duszom zamordowanych świętych i czystych, którzy zostali zabici tu, w świętej gminie Sandomierz w dniu 15 nisan roku 415 według skróconej rachuby: rabina przewodniczącego sądu i rektora jesziwy, przywódców, ludzi wybitnych - mężczyzn, kobiet i ich dzieci, młodzieńców i dziewcząt, wdów, funkcjonariuszy gminy oraz gości, którzy byli tu podczas tego nieszczęścia. Oby Bóg zlitował się nad nimi i nad resztą Izraela, i nie dopuścił do przyjścia niszczyciela do reszty Izraela — nad duszami świętych i czystych, których krew została przelana tu jak woda ${ }^{36}$, w świętej gminie Sandomierz, ponieważ cała święta gmina

${ }^{36}$ Ps 79,3 . 
ślubowała pamięć ich dusz, dusz świętych i czystych: morenu pana Szmuela syna reb Jony, morenu reb Beniamina syna reb Cadoka, kobiety pani Hindy córki reb Cadoka, kobiety pani Blumy córki reb Eliezera, morenu reb Naftalego syna reb Icchaka, morenu reb Menachema Natana syna reb Szmuela Zunwila Halewi, morenu reb Chaima syna reb Icchaka, reb Chaima syna reb Judy Leiba, Gabriela syna morenu pana Beniamina, morenu reb Chaima syna reb Mosze, mlodzieńca Icchaka syna chawera ${ }^{37}$ reb Cwi, morenu pana Aleksandra syna chawera reb Chaima, kobiety pani Pesil córki chawera reb Pinchasa oraz ich dzieci: dziewczyny Sary, młodzieńca Beniamina Binisza i chłopca Chaima - dzieci chawera reb Aleksandra, chawera reb Dawida syna chawera reb Mordechaja Matila [syna] morenu reb Aleksandra syna Isachara ha-Kohena, rabina wielkiej światłości morenu pana Naftalegi Hirca syna morenu reb Szmuela oraz jego zięcia morenu reb Szmarię Szmerila syna morenu reb Eliezera, morenu reb Jom Tow Lipmana syna morenu reb Meira, morenu reb Beniamina syna morenu reb Chaima, morenu pana Cwi syna morenu reb Icchaka, morenu pana Icchaka syna morenu reb Josefa ha-Kohena, morenu pana Jedidię szamesa; Świętych ze świętej gminy Dzików: morenu pana Mosze syna morenu reb Isachara Bera, morenu reb Jehudy i morenu reb Joski - synów reb Mosze Meszla, morenu reb Akiwy syna reb Mosze, wielkiego światła morenu reb Szniora syna morenu reb Szlomo Zalmana, jegi i jego syna morenu reb Szmerila syna morem reb Meira, morenu reb Jakowa i chawera reb Rubena, morenu reb Dawida syna morenu reb Samsona, morenu reb Mosze syna morenu reb Awrahama, morenu reb Dowa syna morenu reb Jehudy, morenu reb Dawida syna morenu reb Szmuela, kobiety Frejdy córki chawera reb Jehudy Lejba, Lei córki morenu reb Dowa Halewi, dziewczyny Geli córki morenu reb Meira, Szprincy córki chawera reb Eliezera Lipy Halewi, Neszy córki morenu reb Cwi Halewi, dziewczyny Towy córki morenu reb Aharona Cwi, rodziny reb Meira „bystrego”, rabina morenu reb Josefa syna moremu reb Mosze Chaima, jego żony rabinowej Racheli córki morenu reb Israela, kobiety Fajgi córki morenu reb Josefa Zeewa, rabina morenu reb Icchaka syna morenu reb Jeszai, morenu reb Jakowa syna morenu reb Josefa, morenu reb Josefa syna morenu reb Szlomy i jego żony Sary córki morenu reb Szlomy, kobiety Miriam Magdeszi córki morenu reb Jehudy, reb Chaima syna morenu reb Zacharii, morenu reb Szragi Fajwla syna morenu reb Isachara Bera. Boże zemsty, Boże, gdzie Twój gniew i Twoja potęga, spójrz z niebios i zobacz z wyżyn Twojej świętości i chwały, że [wielu] ginie każdego dnia z Twojego powodu, uznaj [to] za ofiarę i całopalenie dla Ciebie. Boże, Panie wojen, wprowadź między nich zamieszanie, dlaczego mają mówić narody: „Gdzie jest ich Bóg? ${ }^{38}$ Zaprawdę niech odpłaci im odpowiednio do ich uczynków ${ }^{39}$ ". Tak więc niech ukryje ich Pan miłosierdzia w cieniu Swoich skrzydeł na wieki i wplecie ich dusze w wieniec życia. Bóg jest ich dziedzictwem i będą spoczywać na swoich łożach w ogrodzie Edenu. Ziemio, nie zakrywaj ich krwi, aż pomści [ja] Bóg pochwalony, aby nie był pogardzany wśród ludów; Bóg zemsty, Bóg - on to pomści ich i odpłaci za krew Swoich pobożnych — dla naszych oczu, rychło, za dni naszych. Amen.

${ }^{37}$ chawer (hebr. חבר, ,towarzysz”) - tytuł honorowy nadawany uczonym, nicposiadającym kwalifikacji rabinicznych. $Z$ czasem tytul ten zdeprecjonowal się (por. wyżj przyp. do tckstu nr 1).

${ }_{38}^{38} \mathrm{Jl} 2,17$.

${ }^{39}$ Ps $28,4$. 
6. Elegia upamiętniająca zabitych w 1655 roku w Sandomierzu, autorstwa Jakowa ben Menachema

יהמו קרבי יזלו דמעי עיני עלי מחץ ורוב מכות והלחץ אשר לחצו מעני

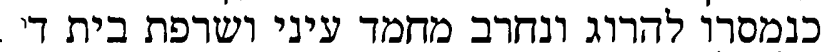

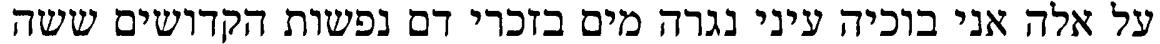

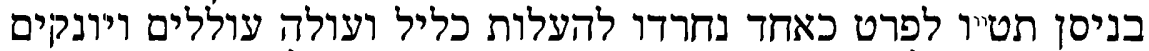

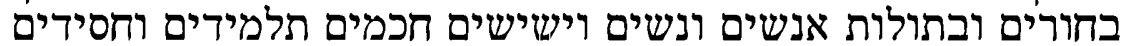

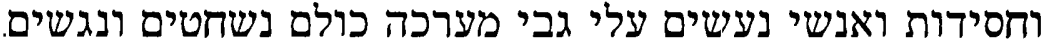

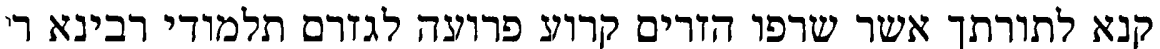

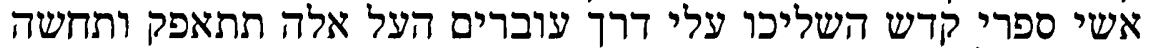
הרואה כל הנסי ספרי דשרים

בקהלא צויזמיר המסולאים כלים בפז נשמו בחוצות האומנים עצלי תולע חבקו

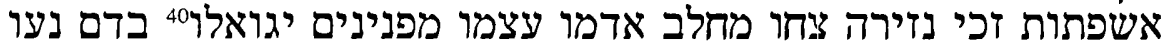
בחוצות כמו טיט נדתות נדשו ונשלכו בחירו בחוצות.

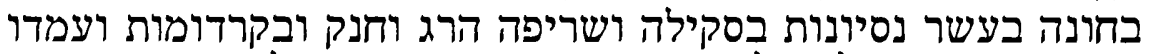

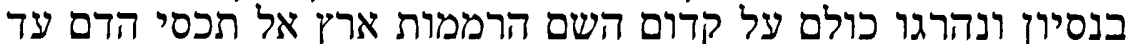
ישקוף הי וינקום אל נקמות הדם אשר שפכו בחוץ ונשלכו לתוך

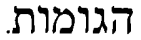
ראה והביטה בפרפורך גויותיהם ליום נקם רצה דמיהם וינקום בימינו

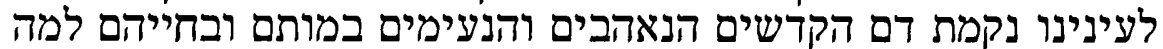

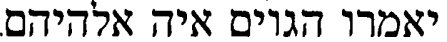

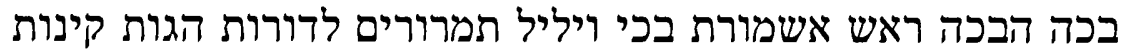
ומספר אבל שורות שורות על על שריפה התורה ועל עם דיל די אשר נפלו בחרב ובמיתות משונות והפרמורות. ידו פרש צר על מחמיר עיני בחגוי סלע בסתר המדרגה שמוני מעצי

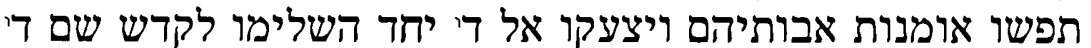

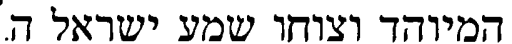

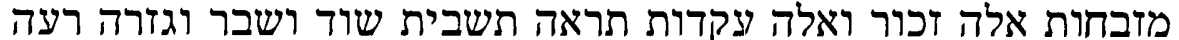

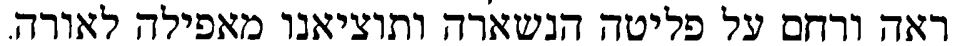

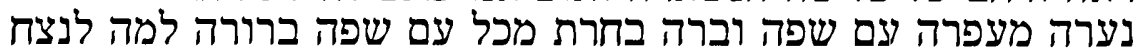

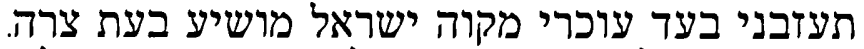

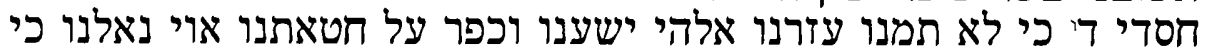

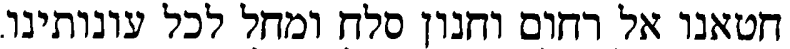

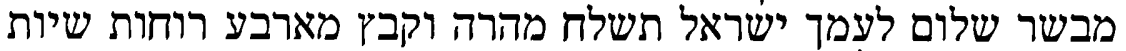
פזורות והשב לנויהם ברנה ובנה בימינו בית הבחירירה

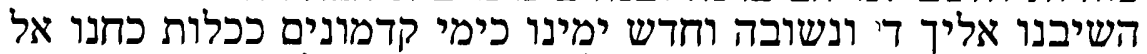

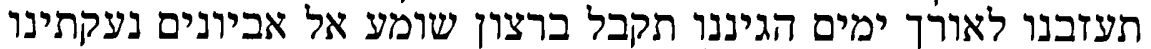
שעה ברחמים כרחם אבעל בעורים ינים

(D. Kandel, op. cit., s. 114$)^{41}$

40 Wydawca zapisat błçdnie „רגואלו".

${ }^{41}$ Imię autora ukryte jest w pierwszych literach wersów. 
Będzie jęczeć moja dusza i popłyną łzy z moich oczu nad ranami, licznymi ciosami i opresjami, które zadali moi oprawcy, kiedy zostaliśmy wydani na śmierć i została zgładzona najukochańsza mi rzecz i spalony dom Boży.

Nad tym ja płaczę, moje oczy leją łzy, na wspomnienie krwi świętych dusz, 6 dnia miesiąca nisan 415 roku. Jak jeden zostali wezwani, aby stać się ofiarą palną i ofiarą calopalną: niemowlęta i dzieci, młodzieńcy i dziewczęta, mężczyźni i kobiety, i sędziwi mędrcy, uczniowie, pobożni i pobożne, ludzie czynu kolejno wszyscy zostali zabici i zadręczeni.

Mścij się za Twoją Torę, którą spalili obcy, podartą na strzępy i rozrzuconą, Talmud rabina reb Aszi - święte księgi, które rzucili na drogę przechodniów. Czy zniesiesz to i zachowasz milczenie Ty, który widzisz wszystkie rzeczy ukryte? ${ }^{42}$

W gminie Sandomierz najdrożsi ${ }^{43}$ byli prześladowani na ulicach, noszący szkarłatne szaty przytulili się do śmietnisk ${ }^{44}$, czyści jak mniszka - bielsi od mleka ${ }^{45}$ stali się czerwoni, [a] ci, którzy byli jak perły, stali się zbrukani krwią, chodzili po ulicach jak błoto, zostali podeptani i rozrzuceni na ulicach ${ }^{46}$.

Poddani dziesięciu próbom - ukamieniowaniu, spaleniu, zamordowaniu, uduszeniu, ścięciu - wytrzymali próbę i wszyscy zostali zamordowani dla uświęcenia najwyższego Imienia Bożego. Ziemio, nie zakrywaj ich krwi, aż Bóg, Bóg zemsty, uderzy i pomści ich krew, którą przelano na ulicach i wylano do dołów.

Patrz i przyglądaj się agonii ich cial, w dniu zemsty odpłać za ich krew! I pomścij — za naszych dni, na naszych oczach — krew świętych ukochanych i miłych w ich śmierci i za ich życia.

Dlaczego mają mówić narody: „Gdzie jest ich Bóg?”47.

Niech rozlega się o zmroku płacz i gorzkie lamenty dla pokoleń, odmawiane linijka za linijką elegie i żałobne opowieści o spaleniu Tory i o narodzie Bożym, który zabito mieczem i różnymi strasznymi rodzajami śmierci.

Wróg wyciągnął rękę po moją najukochańszą rzecz; w wąwozy skalne, w kryjówki tarasów zapędzili mnie ${ }^{48}$. Z powodu nieszczęścia jęli się sposobu swoich przodków i wzywali Boga, jednoczyli się wszyscy,

${ }^{42}$ Dn 2, 22.

${ }^{43}$ Dosł.: "podobni czystcmu złotu”.

${ }_{44} \operatorname{Lm~4,5.}$

${ }^{45} \operatorname{Lm~} 4,7$.

${ }_{46}$ Ps 18,43 .

${ }^{47} \mathrm{Jl} 2,17$.

${ }^{48} 1 \mathrm{Sm} \mathrm{13,6.}$ 
aby święcić Imię Boga, i krzyczeli „Słuchaj, Izraelu, jest Bóg”49.

Pamiętaj te ołtarze i patrz na te akedy, wstrzymaj łupiestwo, zniszczenie i niegodziwe dekrety. Patrz i zmiłuj się nad pozostałymi ocalonymi, i wyprowadź nas z ciemności do światła.

Otrząśnij z prochu naród języka i wybierz ze wszystkich narodów jasnego języka. Dlaczego zawsze będziesz opuszczać mnie na rzecz sprawców nieszczęść zgromadzenia Izreala, wybawicielu w czasie kłopotów?

Ponieważ łaski Boga są nieskończone, wspieraj nas, Boże naszego zbawienia, i przebacz nasze grzechy. Ach, zostaliśmy ciężko doświadczeni, gdyż grzeszyliśmy! Boże miłosierny i laskawy, wybacz i powstrzymaj wszystkie nasze cierpienia.

Ześlij zwiastuna pokoju Twemu narodowi Izraelowi rychło i zgromadź z czterech stron [ziemi] rozproszone jagnięta ${ }^{50}$, i przywróć do ich siedzib ze śpiewem, i zbuduj za dni naszych Świątynię.

Sprowadź nas do siebie, Boże, a wrócimy! I odnów nasze dni, jak dni przodków, gdyż słabe są nasze siły. Nie opuszczaj nas na długie dni, chroń nas, przyjmij chętnie - [Boże] wysłuchujący biedaków — nasze lamenty, rozważ z miłosierdziem, jak ojciec lituje się nad dziećmi.

\section{Elegia upamiętniająca nieszczęścia 1656 roku}

אל מלא רחמים, שוכן בגבהי מרומים, המציא מנוחה נכונה למעלה מים מים

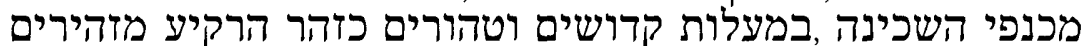

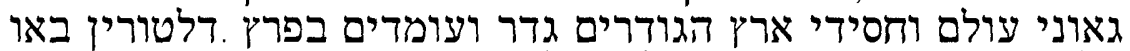
עליהם במרמה ובכזבים, ושלחו עליה וריהם הטמאים היפונים בפרים וטרפו אותם באם

כזאבים.

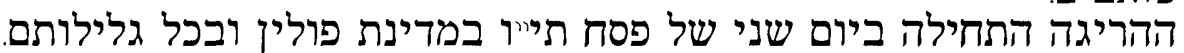

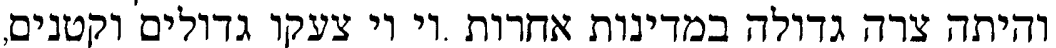

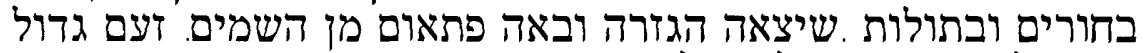
היה עלינו מאדון עולם. שלקח מאתנו גובות גאונים הקדושים מושים המדריכים אותנו בדרך ישרים.

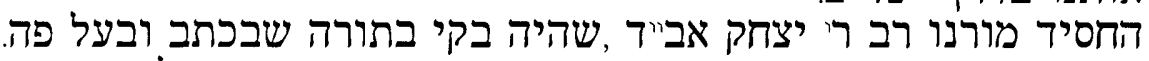

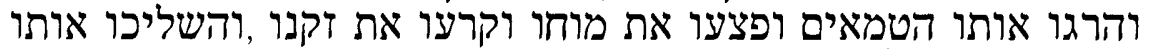
מן החלונות על אשפותה.

טהורה הנשמה של החסים הפיד והישיש מורנו רב רי ישראל ,שהיה מזרע ומים

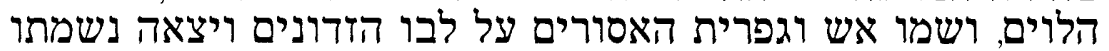
בפסוק שמע ישראל הי אלהינו היתורים אחד.

\footnotetext{
${ }^{49}$ Pwt 4,6

${ }^{50} \mathrm{Jr} 23,3$.
} 
ולא חסועל גופם בעבור קדוש שמו המיוחד .נתיסרו ,נתענו בענוים קשים וגדולים. - ריפולים

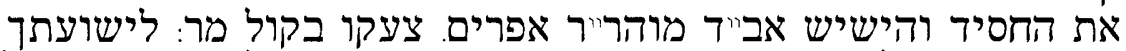
קויתי הי בכפלים. צעק החסיך מהורייר יצחק וקפאו למים יפים. וקראו עליו

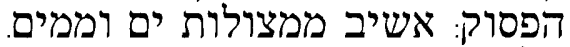

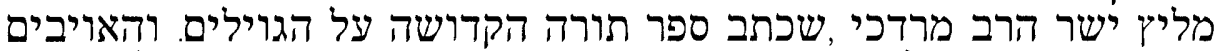

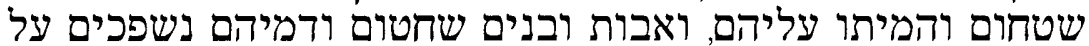

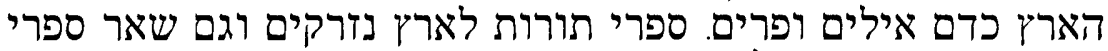
תורות הקרושים נשלכים בחוצות ובשים פרים פרים תורים

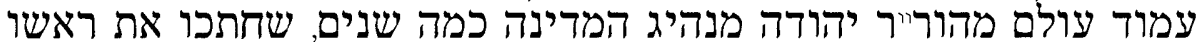

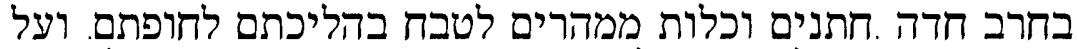

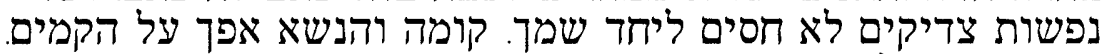

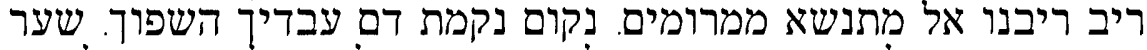

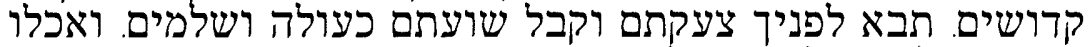

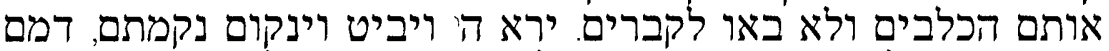

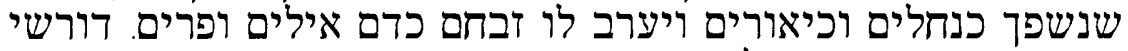

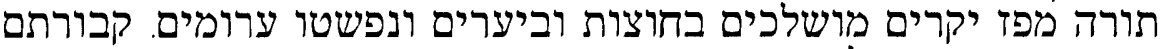
קבורת חמורים. הלא בעבור קדוש שמים מסים מסרו גופם ונים ונשימתם

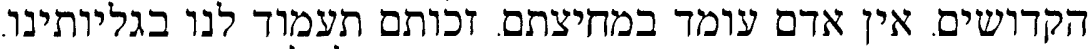

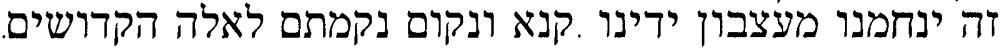

(S. Bernfeld, op. cit., s. 193-194)

Boże pełen miłosierdzia, mieszkający w wysokich niebiosach, daj prawdziwy odpoczynek w górze, pod skrzydłami Szechiny na wysokościach świętych i czystych, lśniących jak blask firmamentu, gaonom świata i pobożnym ziemi, którzy strzegą Prawa i uzupełniają [Je]. Oszczercy wystapili przeciwko nim z falszem i kłamstwami, i wysłali na nich nieczystych Greków ${ }^{51}$, i rozszarpali ich jak wilki.

Mordowanie zaczęło się drugiego dnia Pesach $416^{52}$, w państwie polskim i we wszystkich jego okręgach. I było wielkie nieszczęście w innych państwach. Biada, biada! — krzyczeli duzi i mali, młodzieńcy i dziewczęta. Gdyż wyszedł wyrok i przyszedł rychło z niebios. Wielki gniew miał wobec nas Pan świata. Gdyż zabrał nam świętych gaonów, którzy prowadzą nas drogą sprawiedliwych.

Pobożny morenu rabin reb Icchak przewodniczący sądu, który był znawcą Biblii i Talmudu. I zamordowali go nieczyści i zniszczyli jego umysł, wyrwali mu brodę i wyrzucili go z okien na śmietnisko.

51 W ten sposób określano wyznawców Kościoła prawosławnego.

5227 marca 1656 roku. 
Czysta dusza pobożnego i wiekowego morenu rabina reb Israela, który był z plemienia Lewitów, i podłożyli złoczyńcy ogień i siarkę na jego serce, i odeszła jego dusza podczas [odmawiania] fragmentu „Słuchaj, Izraelu! Pan jest naszym Bogiem. Pan jest jeden!"53.

I nie szkoda im było swoich ciał dla uświęcenia Imienia Bożego.

Cierpieli, męczyli się w ciężkich i wielkich męczarniach.

Pobożnego i wiekowego przewodniczącego sądu morenu reb Efraima.

Wołali dwukrotnie gorzkim głosem: „Twojego wybawienia oczekuję, Boże!" 54 . Wołal pobożny morenu reb Icchak i utopili ${ }^{55}$ [go] w wodzie. I wypowiedzieli nad nim fragment:

"Przywrócę z głębin morza i z wód"56.

Prawy mówca rabin Mordechaj, który przepisywał świętą Torę na pergaminie. I wrogowie rozproszyli ich, sprowadzili na nich śmierć, rozproszyli ojców i dzieci, a ich krew została wylana na ziemię jak krew kozłów i byków. Księgi Tory zostały ciśnięte na ziemię i również pozostałe księgi Tory zostały rozrzucone na ulicach i rynkach.

Podpora świata morenu reb Jehuda, przywódca kraju przez kilka lat, którego głowę odcięli ostrym mieczem. Narzeczeni i narzeczone śpieszą na śmierć w drodze pod swoją chupę ${ }^{57}$. I za dusze sprawiedliwych — nie szukają [oni] ratunku ze względu na Twoje Imię. Pomścij krew Twoich sług, która jest wylewana. Bramo świętych, sprowadź przed Siebie ich wołanie i przyjmij ich płacz jako ofiarę całopalną i ofiarę za pokój. I pożarły ich psy, i nie trafili do grobów. Oby Bóg spojrzał i patrzył, i pomścił ich, ich krew, która została wylana jak rzeki i jeziora, i oby ich ofiara była Mu przyjemna, jak krew kozłów i byków. Kaznodzieje Tory, cenniejsi od złota, rozrzuceni na ulicach i po lasach, i nadzy zostali odarci z szat. Ich pogrzeb jest oślim pogrzebem ${ }^{58}$. Czyż nie dla uświęcenia Twojego Imienia wydali swoje ciała i swoje święte dusze? Nie ma człowieka, który zniósłby ich cierpienia. Ich zasługa będzie podtrzymywać nas w naszym wygnaniu. To pocieszy nas w naszym smutku. Bądź gorliwy i pomścij tych świętych.

${ }^{53}$ Pwt 6, 4.

$54 \mathrm{Rdz} 49,18$.

55 Dosł.: „Zamrozili”.

56 Ps 68, 23.

${ }^{57}$ chupa - baldachim ślubny.

58 Jr 22, 19. 
8. Elegia, którą napisał Aleksander Gutkind ben Mosze ha-Kohen ze świętej gminy Piła

אל מלא רחמים,

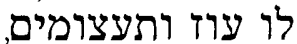

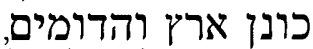
סומך נופלים לעולמים.

ורא תהלות ותפלות, דורש דמים ועלילות נחלות, רואה נסתרות והנים ועלילותות, גומל חסדים וגמולותות.

ולמה תביט צרים טמאים הרגו טהורים צולים קהלות גדולות היגות היקרים, יודעי-שמך הישרים. - (ארות

נסקלו ונשרפו ונהרגו ונחנקו, דמית אחיך צעקו, - בעותות במיתות משנות לקוּ, נתינות רחמיך צעקו.

מכל-ספרי תורות ומכל-ספרים היקרות השחיתו לסנדלים הכיקרות מסמרות, רמסו ושרפו הנותרות.

רדפו אבות ובנים, מורי צרק הרבנים, אבובנים, שופטי צרק הגאונים האם על בנים.

כל-אלו העקרות, הריגות חסידים וחערותידות, נמסרו בגזרות ושמדות - וחסירות זכור לשארית ידידות.

לעקדת יצחק נשבעת, הרבות זרעו הבטחתי יעשת,

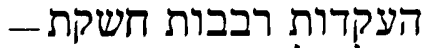
העל אלה התאפקות!

מתי תעשה נקמה, 


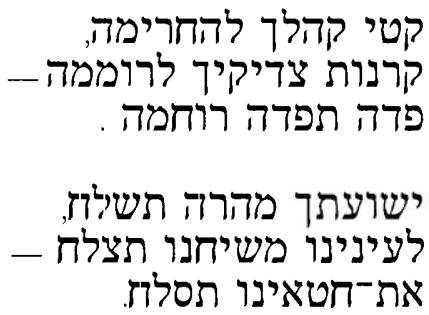

(S. Bernfeld, op. cit., s. 197-199) ${ }^{59}$

Bóg pełen miłosierdzia,

którego jest siła i moc,

chroni ziemię i [jej] podstawy,

przybliża zabitych do wieczności.

Jest poruszony psalmami i modlitwami,

pragnie krwi i oskarżeń,

widzi rzeczy ukryte i jawne,

odpłaca miłosierdzie i dobre uczynki.

I dlaczego będziesz się przyglądał wrogom:

nieczyści zamordowali czystych,

gminy wielkie, drogich,

uczciwych - znających Twoje imię.

Ukamienowani, spaleni, zamordowani i uduszeni,

krew twego brata wolała,

różnymi rodzajami śmierci zostali doświadczeni,

darów Twego miłosierdzia wzywali.

Wszystkie zwoje Tory

i wszystkie drogie księgi

zniszczyli na okute sandaly,

stratowali i spalili resztki.

Prześladowali ojców i synów,

nauczycieli sprawiedliwości — rabinów,

sędziów sprawiedliwości - gaonów,

matki dzieciom.

Wszystko to są akedy,

zabijanie pobożnych mężczyzn i kobiet,

${ }^{59}$ Imię autora ukryte jest w picrwszych litcrach wersów. 
zostali wydani na prześladowania i konwersje pamiętaj o pozostałych ukochanych.

Ze względu na Akedę Icchaka przysiagłeś, liczne mu potomstwo obiecałeś, wiele aked związałeś czy ze względu na to powstrzymałeś się!?

Kiedy wymierzysz zemstę?

Nie chciej zniszczenia Twojej wspólnoty, rzeszę Twoich sprawiedliwych dla chwały w miłosierdziu zaprawdę uratujesz.

Ześlij rychło Twoje zbawienie, naszego mesjasza ukaż naszym oczom, nasze grzechy wybacz. 